Finanse, Rynki Finansowe, Ubezpieczenia nr 3/2017 (87), cz. 1

\title{
Analiza funkcjonowania audytu wewnętrznego w Polsce w aspekcie obowiązujących regulacji prawnych
}

\author{
Katarzyna Sojka*
}

\begin{abstract}
Streszczenie: $\mathrm{Cel}$ - Analiza funkcjonowania audytu wewnętrznego w Polsce w aspekcie obowiązujących regulacji prawnych.

Metodologia badania - Analiza porównawcza, wnioskowanie logiczne.

Wynik - Wskazanie rozwiązań prawnych, których funkcjonowanie wpływa na działanie jednostek sektora finansów publicznych oraz ocenę audytu wewnętrznego.

Oryginalność/wartość - Analiza regulacji prawnych definiujących funkcjonowanie audytu wewnętrznego umożliwiła wskazanie rozwiązań wpływających na skuteczność zorganizowanego systemu kontroli i nadzoru wynikającego z negocjacji akcesyjnych Polski z UE. Interpretację przepisów prawnych poparto badaniami empirycznymi. Wartość naukową pracy stanowi poszerzenie wiedzy w zakresie oddziaływania regulacji prawnych dotyczących audytu wewnętrznego.
\end{abstract}

Słowa kluczowe: audyt wewnętrzny, analiza regulacji prawnych, ocena wprowadzania i koordynacja audytu, kryteria oceny audytu wewnętrznego

\section{Wprowadzenie}

Idea uregulowania audytu wewnętrznego w sektorze publicznym związana była z negocjacjami akcesyjnymi Polski z Unią Europejską. W wyniku negocjacji strona polska zobowiązała się do zorganizowania zintegrowanego systemu kontroli i nadzoru (Tylka, 2005, s. 8). Nowelizacja ustawy o finansach publicznych z 2001 roku stanowiła ramy dla działalności audytu wewnętrznego oraz formalny wyraz dostosowania się do warunków akcesji (Babuśka, 2011, s. 94).

Audyt przez ponad 15 lat funkcjonowania przeszedł znaczące zmiany prawne. Kierunek tych zmian ujednolicił formę kontroli na poziomie ustawy w całym sektorze publicznym oraz zbliżył polskie regulacje do tych wypracowanych przez międzynarodowe organizacje audytowe. Obowiązujące regulacje prawne nie rozwiązały ostatecznie wielu problemów praktycznych związanych ze stosowaniem audytu wewnętrznego. Zmiany wprowadzane kolejnymi ustawami o finansach publicznych postawiły przed audytorami nowe wyzwania w kwestiach zarówno ustrojowych, jak i metodyki audytu (Chojna-Duch, 2012, s. 337).

\footnotetext{
* mgr inż. Katarzyna Sojka, Uniwersytet Ekonomiczny w Poznaniu, e-mail: kasia_jablonska@poczta.onet.pl.
} 


\section{Regulacje prawne audytu wewnętrznego w sektorze publicznym}

Audyt wewnętrzny został wprowadzony w 1998 roku ustawą o finansach publicznych. Ustawa definiowała audyt, jako ogół działań, dzięki którym kierownik jednostki uzyskuje obiektywną i niezależną ocenę funkcjonowania jednostki w zakresie gospodarki finansowej, pod względem legalności, gospodarności, celowości, rzetelności, a także przejrzystości i jawności (Ustawa, 1998). Nowelizacja ustawy o finansach publicznych z 2005 roku zmieniła podejście audytu wewnętrznego, kierując go w stronę ogółu działań obejmujących badanie systemów zarządzania i kontroli w jednostce, w tym procedur kontroli finansowej. W wyniku niezależnego badania, kierownik jednostki uzyskiwał obiektywną i niezależną ocenę adekwatności, efektywności i skuteczności tych systemów. Działania obejmowały także czynności doradcze, mające na celu usprawnienie funkcjonowania jednostki (Ustawa, 2005). Obecnie obowiązująca ustawa o finansach publicznych z 2009 roku określa audyt jako działalność niezależną i obiektywną, której celem jest wspieranie ministra kierującego działem lub kierownika jednostki w realizacji celów i zadań przez systematyczną ocenę kontroli zarządczej oraz czynności doradcze. Ocena dotyczy w szczególności adekwatności, skuteczności i efektywności kontroli zarządczej w dziale administracji rządowej lub jednostce (Ustawa, 2009).

Wielokrotne nowelizacje ustawy nie poszerzyły liczby jednostek sektora finansów publicznych zobowiązanych do prowadzenia audytu wewnętrznego. Zapisy ustawy o finansach publicznych zobowiązywały kierowników jednostek do wprowadzenia audytu wewnętrznego przy poziomie uzyskania wydatków od $35 \mathrm{mln}$ zł według rozporządzenia z 2002 roku (Rozporządzenie, 2002) a obecnie od 40 mln zł określonych w ustawie. Wprowadzono w ustawie o finansach publicznych z roku 2009 zapisy umożliwiające prowadzenie audytu w jednostkach sektora finansów publicznych, których kierownicy podejmują decyzję o prowadzeniu audytu wewnętrznego, jednak nadal nie jest to obowiązkowe (Ustawa, 2009).

$\mathrm{Z}$ badania ankietowego przeprowadzonego przez Departament Polityki Wydatkowej Ministerstwa Finansów w czerwcu 2016 roku wynika, że przyczyny wystąpienia przerwy $\mathrm{w}$ prowadzeniu audytu wewnętrznego w jednostkach samorządu terytorialnego spowodowane były między innymi zmniejszeniem progu dochodowego i przychodów lub wydatków i rozchodów - dotyczyło to 14\% jednostek badanych (Ocena funkcjonowania ..., 2016, s. 10). Oznacza to, że jednostki te zostały wyłączone z zorganizowanego, zintegrowanego systemu kontroli i nadzoru, do którego strona polska zobowiązała się w toku negocjacji akcesyjnych Polski z Unią Europejską. Z benchmarkingu audytu wewnętrznego przeprowadzonego przez Departament Polityki Wydatkowej w roku 2014 wynika, że ponad 16\% jednostek administracji rządowej było zwolnionych z obowiązkowego prowadzenia audytu wewnętrznego. W związku z powyższym, w jednostkach tych założono możliwość nieprowadzenia systematycznej oceny kontroli zarządczej w aspekcie adekwatności, skuteczności i efektywności, którą powierzono zapisami ustawy o finansach publicznych komórkom audytu 
wewnętrznego. Strukturę jednostek administracji rządowej według poziomu wydatków lub kosztów zaprezentowano na rysunku 1.

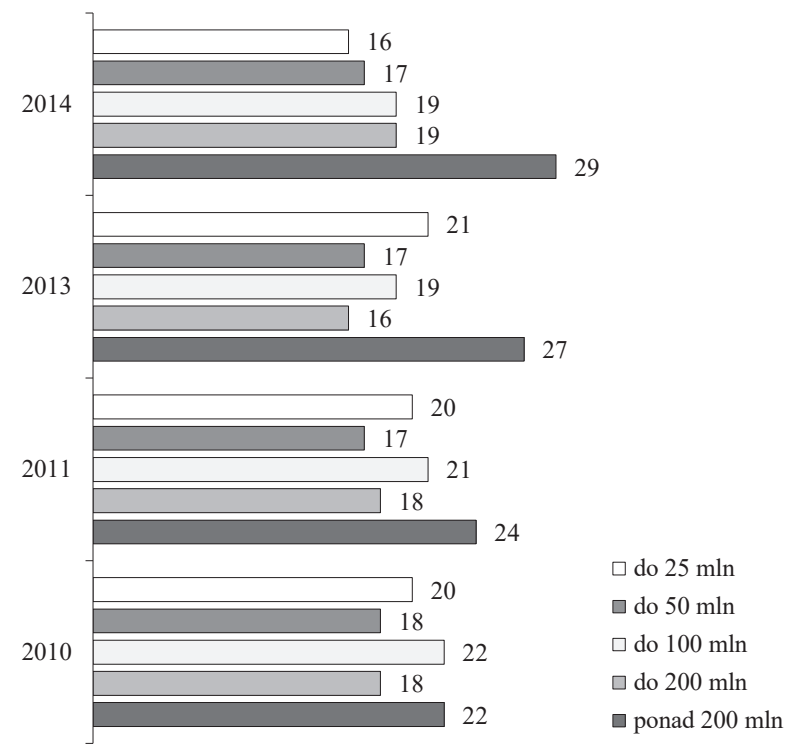

Rysunek 1. Struktura jednostek administracji rządowej według poziomu wydatków lub kosztów w latach 2010-2014 (\%)

Źródło: opracowanie własne na podstawie Benchmarking audytu wewnętrznego jednostek sektora finansów publicznych (2011), s. 10; (2012), s. 7; (2013), s. 8; (2015), s. 8.

Przyjmując założenia, że około 20\% jednostek sektora rządowego dysponuje budżetami w wysokości $25 \mathrm{mln}$ zł, umożliwiającymi nieprowadzenie audytu w jednostce, to kwota środków finansowych nieobjętych kontrolą i nadzorem bieżącym poprzez ocenę komórki audytu wewnętrznego jest znaczna. Kwota wydatkowanych publicznych środków finansowych wyłączona $\mathrm{z}$ oceny audytu wewnętrznego ulegnie zwiększeniu, uwzględniając również sektor samorządowy jednostek o budżetach do $40 \mathrm{mln}$ zł.

Zarówno ustawa o finansach publicznych z 2009 roku, jak i wcześniejsze ustawy różnicowały poziom koordynacji audytu wewnętrznego w Polsce na sektor rządowy i samorządowy. Zapisem art. 62 ustawy o finansach publicznych z 2005 roku określono, że organem administracji rządowej właściwym w sprawach koordynacji kontroli finansowej i audytu wewnętrznego w jednostkach sektora finansów publicznych jest Minister Finansów. Zadania Ministra Finansów realizował według ustawy o finansach publicznych z 2005 roku Główny Inspektor Audytu Wewnętrznego. Ustawą o finansach publicznych z 2009 roku, zadania te realizuje Departament Polityki Wydatkowej. Z kolei w odniesieniu do jednostek podsektora samorządowego kompetencje w zakresie Głównego Inspektora Audytu Wewnętrznego a później Departamentu Polityki Wydatkowej przekazano wójtom, burmistrzom, 
starostom, marszałkom województwa (Ustawa, 2005; 2009). W wyniku podziału koordynacji audytu wewnętrznego w jednostkach sektora finansów publicznych, Minister Finansów nie ma pełnej wiedzy w zakresie funkcjonowania audytu wewnętrznego w sektorze samorządowym.

W czerwcu 2016 roku Departament Polityki Wydatkowej Ministerstwa Finansów skierował do kierowników 2808 jednostek samorządu terytorialnego ankietę dotyczącą funkcjonowania kontroli zarządczej i prowadzenia audytu wewnętrznego w jednostkach. Z uwagi na nieobowiązkowy charakter ankiety, wynikający z braku koordynacji przez Ministerstwo Finansów tego sektora, w badaniu wzięły udział 1423 jednostki, co stanowiło 50,6\% badanej populacji. Pozostałe 49,4\% podsektora samorządowego nie uczestniczyło w badaniu (Ocena funkcjonowania..., 2016, s. 4). Wątpliwości w zakresie powierzenia kompetencji Departamentu Polityki Wydatkowej wójtom, burmistrzom, prezydentom, starostom związane są z kadencyjnością kierowników jednostek sektora samorządowego oraz doświadczeniem w zakresie koordynacji audytu wewnętrznego w przeszłości (Ustawa o samorządzie, 2016). Różnice w zakresie koordynacji audytu wewnętrznego w zależności od sektora wpłynęły na ochronę stosunku pracy audytorów wewnętrznych w sektorze samorządowym. Ustawą o finansach publicznych z 2009 roku zniesiono ochronę stosunku pracy audytorom z sektora samorządowego. Ochrona stosunku pracy pozostała tylko w odniesieniu do kierowników komórek audytu zatrudnionych w sektorze rządowym, ponieważ w aspekcie art. 281 ustawy o finansach publicznych z roku 2009 rozwiązanie stosunku pracy ani zmiana warunków płacy nie może nastąpić bez zgody Komitetu Audytu (Rozporządzenie, 2009), którego w sektorze samorządowym nie powołano (Ustawa, 2009). Schemat koordynacji audytu wewnętrznego $\mathrm{w}$ jednostkach sektora finansów publicznych zaprezentowano na rysunku 2.

$\mathrm{Z}$ przeprowadzonego badania ankietowego $\mathrm{w}$ zakresie funkcjonowania audytu wewnętrznego w samorządach gminnych skierowanego do audytorów wewnętrznych ustalono, że skuteczność przeprowadzania audytu zależy między innymi od warunków organizacyjnych komórki audytowej. Zdaniem 70\% ankietowanych obsada przynajmniej dwuosobowa pozwoliłaby na konsultacje w zakresie realizacji zadań audytowych. $Z$ grupy ankietowanej $25 \%$ badanych zadeklarowało, że realizuje inne czynności dodatkowe niezwiązane z audytem, np. w zakresie kontroli wewnętrznej czy pomocy prawnej pracownikom. Ustalono, że $20 \%$ badanych określało podległość kierownikowi, jako formalną. Wiele decyzji dotyczących stosunku pracy oraz wynagrodzenia przekazano do kompetencji sekretarza. Zatem według badanych, niezależność audytora wewnętrznego w przypadku sektora samorządowego może budzić wątpliwości. Powodem takiej oceny uregulowań prawnych jest równocześnie nieprzekazywanie planu audytu i sprawozdania z jego wykonania do Ministerstwa Finansów. Jedynym odbiorcą sprawozdania jest kierownik jednostki (wójt, burmistrz, prezydent). W grupie respondentów pozytywnie oceniono art. 284 Ustawy o finansach publicznych z 2009 roku umożliwiający radzie gminy, chociaż częściowe zapoznanie się z efektami pracy audytora. W zakresie podległości komórki audytu wewnętrznego, 17,5\% 


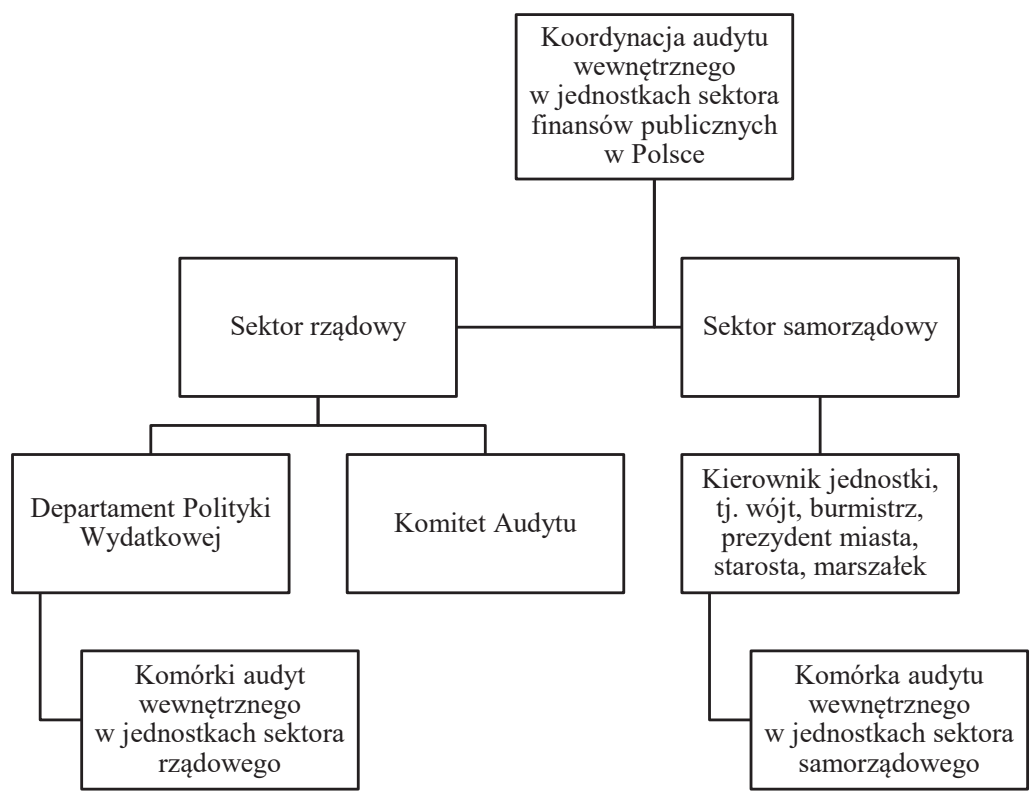

Rysunek 2. Struktura koordynacji audytu wewnętrznego w jednostkach sektora finansów publicznych w Polsce

Źródło: opracowanie własne na podstawie Ustawa z dnia 27 sierpnia 2009 r. o finansach publicznych (t.j. Dz.U. 2016, poz. 1870 z późn. zm.).

audytorów proponuje Ministerstwo Finansów lub Regionalną Izbę Obrachunkową ${ }^{1}$. Obecnie pozycja audytora w sektorze samorządowym zdaniem badanych jest znacznie słabsza niż w jednostkach pionu rządowego. Według respondentów, audytor wewnętrzny powinien mieć umożliwiony dostęp do rady gmin, gdzie mógłby prezentować sprawozdania i zalecenia, które należy wprowadzić (Bartosiewicz, 2012, s. 88-90).

\section{Kryteria oceny audytu wewnętrznego według regulacji prawnych i proponowanych rozwiązań prezentowanych przez ustawodawcę}

Zapisy w zakresie oceny audytu wewnętrznego uregulowano w rozporządzeniach Ministra Finansów. Analizując zapisy poszczególnych rozporządzeń (Rozporządzenia Ministra Finansów, 2002, 2006, 2008, 2010, 2015) ustalono, że ostatnia regulacja ma syntetyczny charakter i nie wyjaśnia szczegółowo metodologii prowadzenia audytu. W związku z tym Departament Polityki Wydatkowej przygotował dokumentację obejmującą komentarze i wyjaśnienia do wprowadzonego aktu prawnego (Rozporządzenie - Komentarz, 2015).

\footnotetext{
${ }^{1}$ Regionalna Izba Obrachunkowa - organ kontrolny.
} 
Uregulowanie kwestii oceny audytu wewnętrznego przez pracowników Ministerstwa Finansów określono w rozporządzeniach z 2010 i 2015 roku (Rozporządzenie Ministra Finansów, 2010; 2015). Zapisy obowiązującego rozporządzenia z 2015 roku regulują uprawnienia osób przeprowadzających ocenę oraz audytowanych.

Metody oceny audytu wewnętrznego w ramach wymagań dotyczących programu zapewnienia i poprawy jaskości uregulowano Komunikatem Ministra Rozwoju i Finansów z 2016 roku w sprawie standardów audytu wewnętrznego dla jednostek sektora finansów publicznych (Dz. Urz. Min. Roz. i Fin. poz. 28). Zasadniczym celem programu zapewnienia i poprawy jakości jest umożliwienie dokonania oceny czy działalność audytu wewnętrznego jest zgodna ze standardami, oraz czy audytorzy wewnętrzni stosują kodeks etyki. Program służy także do oceny wydajności i skuteczności audytu wewnętrznego oraz do identyfikacji możliwości poprawy (Komunikat Ministra Finansów, 2016, s. 28). Departament Audytu Sektora Finansów Publicznych w celu stałego podnoszenia jakości audytu wewnętrznego w sektorze publicznym wprowadził w 2011 roku benchmarking ${ }^{2}$ audytu. Raporty benchmarkingu opracowano dla 2011, 2012, 2013, 2015 roku. Zaprezentowano w nich wyniki badania wybranych wskaźników opisujących komórki audytu wewnętrznego i wyniki ich pracy. W tabeli 1 zaprezentowano wykaz wskaźników wyników ujętych w badaniach benchmarkingowych w latach 2011-2015.

\section{Tabela 1}

Wykaz wskaźników oceny audytu wewnętrznego

\begin{tabular}{|c|c|c|c|c|}
\hline Nazwa wskaźnika & 2011 & 2012 & 2013 & 2015 \\
\hline \multirow[t]{3}{*}{$\begin{array}{l}\text { Wskaźniki } \\
\text { wyników audytu } \\
\text { wewnętrznego }\end{array}$} & $\begin{array}{l}\text { liczba zakończonych } \\
\text { zadań zapewniają- } \\
\text { cych }\end{array}$ & $\begin{array}{l}\text { liczba zakończonych } \\
\text { zadań zapewniają- } \\
\text { cych }\end{array}$ & $\begin{array}{l}\text { liczba zakończonych } \\
\text { zadań zapewniają- } \\
\text { cych }\end{array}$ & $\begin{array}{l}\text { liczba zakończonych } \\
\text { zadań zapewniają- } \\
\text { cych }\end{array}$ \\
\hline & $\begin{array}{l}\text { liczba zakończonych } \\
\text { czynności dorad- } \\
\text { czych }\end{array}$ & $\begin{array}{l}\text { liczba zakończonych } \\
\text { czynności dorad- } \\
\text { czych }\end{array}$ & $\begin{array}{l}\text { liczba wydanych } \\
\text { zaleceń }\end{array}$ & $\begin{array}{l}\text { liczba wydanych } \\
\text { zaleceń }\end{array}$ \\
\hline & $\begin{array}{l}\text { liczba wydanych } \\
\text { zaleceń }\end{array}$ & $\begin{array}{l}\text { liczba wydanych } \\
\text { zaleceń }\end{array}$ & & \\
\hline
\end{tabular}

Źródło: opracowanie własne na podstawie Benchmarking... (2011, 2012, 2013, 2015).

Analiza wskaźników obejmująca poziom realizacji zadań zapewniających, nie uwzględnia poziomu ryzyka realizowanego zadania audytowego. Poziom ryzyka powinien być uwzględniany na etapie planowana zadania, zapewniającego obejmującego rozliczenie osobodni. Liczba osobodni na realizację zadania zapewniającego przy najwyższym priorytecie związanym z ryzykiem wysokim może stanowić nawet 90 osobodni, podczas gdy realizacja

\footnotetext{
${ }^{2}$ Benchmarking (badania porównawcze lub analiza porównawcza) - praktyka stosowana w zarządzaniu, polegająca na porównaniu procesów i praktyk stosowanych przez własne przedsiębiorstwo, ze stosowanymi w przedsiębiorstwach uważanych za najlepsze z analizowanej dziedzinie. Wynik takiej analizy służy jako podstawa doskonalenia.
} 
zadania audytowego o priorytecie poniżej 30\% zakłada maksymalnie 30 osobodni (Podręcznik audytu..., 2003, s. 60). W związku z analizą porównywania liczby zakończonych zadań zapewniających bez uwzględnienia tego aspektu może budzić wątpliwości.

Porównywanie poziomu realizacji czynności doradczych, bez uwzględnienia ich specyfiki, tj. opinia, szkolenie także nie umożliwia jednoznacznej oceny tego wskaźnika. Liczba osobodni w zależności od tego czy audytor wydaje opinię czy realizuje szkolenie może być zróżnicowana. Ponadto przy braku sformalizowania wykonywania czynności doradczych wpływających na ocenę długości realizacji zadania doradczego oraz uwzględnienia potrzeb kierownictwa danej jednostki prowadzenie oceny z uwzględnieniem omawianego wskaźnika może nie być wiarygodne. Nieujęcie tego wskaźnika w benchmarkingach za 2013 i 2015 rok może świadczyć o występowaniu wątpliwości w zakresie możliwości oceny audytu wewnętrznego także ze strony Ministerstwa Finansów.

Wątpliwości związane ze stosowaniem wskaźnika obejmującego liczbę wydanych zaleceń dotyczą nieuwzględnienia, poza profesjonalizmem audytora, jakości wykonywania zadań przez jednostkę audytowaną. W przypadku jednostek sektora finansów publicznych prawidłowo zarządzanych, zatrudniających kadrę poziomu operacyjnego oraz kadrę poziomu strategicznego o wysokich kompetencjach i doświadczeniu zawodowym, ryzyko związane z nieprawidłową realizacją procesu czy stosowaniem nieefektywnych rozwiązań maleje. Ponadto we wskaźniku tym nie uwzględniono, że jeden proces może być realizowany zgodnie $\mathrm{z}$ procedurami przyjętymi w jednostce, a inny nie. W przypadku stosowania tego wskaźnika w ocenach audytu wewnętrznego może wystąpić sytuacja, w której audyt wewnętrzny $\mathrm{z}$ uwagi na funkcjonowanie $\mathrm{w}$ jednostce o wysokim ryzyku wystąpienia nieprawidłowości zostanie oceniony pozytywniej niż audyt $\mathrm{w}$ jednostce realizującej procesy wzorcowo. Może to doprowadzić do sytuacji, w której audyt wewnętrzny w sposób ograniczony będzie dążył do usprawniania procesów w jednostce.

\section{Uwagi końcowe}

W Polsce istnieje wysoki poziom zróżnicowania wprowadzania audytu wewnętrznego, co uzależnione jest od specyfiki sektora, w którym występuje. Obowiązujące rozwiązania prawne przyjęte $\mathrm{w}$ Polsce $\mathrm{w}$ zakresie wprowadzenia i koordynacji audytu wewnętrznego, oraz uregulowanie kryteriów oceny audytu, wymagają rozważenia. Przyjęcie progu $40 \mathrm{mln}$ zł regulujące obowiązek wprowadzenia audytu w jednostkach sektora finansów publicznych ograniczyło kontrolę i nadzór w tych jednostkach oraz nie przyczyniło się do podniesienia jakości zarządzania. Rozwiązanie to zwiększyło możliwości wystąpienia ryzyka finansowego i prawnego $\mathrm{w}$ procesach pozbawionych systematycznego monitoringu. Niewprowadzenie koordynacji audytu wewnętrznego ze strony Ministerstwa Finansów w sektorze samorządowym znacznie osłabiło pozycję audytu w tych jednostkach oraz ograniczyło możliwość bieżącej oceny funkcjonowania audytu. 
Istotną kwestią dotychczas nieuregulowaną jest wypracowanie kryteriów oceny audytu poprzez określenie grupy wskaźników. Zaproponowane dotychczas rozwiązania nie zawsze uwzględniają wszystkie zmienne, które wpływają na realizację zadań audytu wewnętrznego. Wypracowanie grupy obiektywnych, transparentnych wskaźników pozwoli na ocenę audytu wewnętrznego sektora jednostek finansów publicznych w sposób jednorodny przez różne organy oceniające ${ }^{3}$.

\section{Literatura}

Bartoszewicz, A. (2012). Praktyka funkcjonowania audytu wewnętrznego w Polsce. Warszawa: CeDeWu.

Babuśka, E.W. (2011). Audyt wewnętrzny w ustawie o finansach publicznych. Poszukiwany model funkcjonowania. Zeszyty Naukowe Polskiego Towarzystwa Ekonomicznego, 10.

Benchmarking audytu wewnętrznego w jednostkach sektora finansów publicznych (2010). Warszawa: Departament Audytu Sektora Finansów Publicznych.

Benchmarking audytu wewnętrznego w jednostkach sektora finansów publicznych (2012). Warszawa: Departament Audytu Sektora Finansów Publicznych.

Benchmarking audytu wewnętrznego w jednostkach sektora finansów publicznych (2013). Warszawa: Departament Audytu Sektora Finansów Publicznych.

Benchmarking audytu wewnętrznego w jednostkach sektora finansów publicznych (2015). Warszawa: Departament Polityki Wydatkowej.

Chojna-Duch, E. (2012). Audyt wewnętrzny w sektorze finansów publicznych - aktualne problemy. Zeszyty Naukowe Uniwersytetu Szczecińskiego, 718. Finanse, Rynki Finansowe, Ubezpieczenia, 53.

Komunikat Ministra Rozwoju i Finansów z dnia 12 grudnia 2016 r. w sprawie standardów audytu wewnętrznego dla jednostek sektora finansów publicznych (Dz. Urz. Min. Roz. i Fin. poz. 28).

Komunikat nr 23 Ministra Finansów z dnia 16 grudnia 2009 r. w sprawie standardów kontroli zarządczej dla sektora finansów publicznych (Dz. Urz. Min. Fin. nr 15, poz. 84).

Międzynarodowe Standardy Praktyki Zawodowej Audytu Wewnętrznego (2012). Warszawa: Tłum. IIA - Polska.

Podręcznik Audytu Wewnętrznego w Administracji Publicznej (2003). Warszawa: Ministerstwo Finansów. Pobrane z: www. mf.gov.pl.

Ocena funkcjonowania kontroli zarzadczej i prowadzenia audytu wewnętrznego $w$ jednostkach samorzadu terytorialnego (2016). Warszawa: Departament Polityki Wydatkowej.

Rozporządzenie Ministra Finansów z dnia 1 lutego 2010 r. w sprawie przeprowadzania i dokumentowania audytu wewnętrznego (Dz.U. nr 21, poz. 108).

Rozporządzenie Ministra Finansów z dnia 4 września 2015 r. w sprawie audytu wewnętrznego oraz informacji o pracy i wynikach tego audytu (Dz.U. poz. 1480).

Rozporządzenie Ministra Finansów z dnia 29 grudnia 2009 r. w sprawie komitetu audytu (t.j. Dz.U. 2016, poz. 2049).

Rozporządzenie Ministra Finansów z dnia 5 lipca 2002 r. w sprawie szczegółowego sposobu i trybu przeprowadzania audytu wewnętrznego (Dz.U. nr 111, poz. 973).

Rozporządzenie Ministra Finansów z dnia 24 czerwca 2006 r. w sprawie szczegółowego sposobu i trybu przeprowadzania audytu wewnętrznego (Dz.U. nr 112, poz. 765).

Rozporządzenie Ministra Finansów z dnia 10 kwietnia 2008 r. w sprawie szczegółowego sposobu i trybu przeprowadzania audytu wewnętrznego (Dz.U. nr 66, poz. 406).

Rozporządzenie Ministra Finansów z dnia 4 września 2015 r. w sprawie audytu wewnętrznego oraz informacji o pracy i wynikach tego audytu. Komentarze i wyjaśnienia. Warszawa: Departament Polityki Wydatkowej.

Rozporządzenie Ministra Finansów z dnia 20 grudnia 2002 r. w sprawie określenia kwot przychodów oraz wydatków środków publicznych dokonywanych w ciągu roku kalendarzowego, których przekroczenie powoduje obowiązek prowadzenia audytu wewnętrznego w jednostkach sektora finansów publicznych (Dz.U. nr 234, poz. 1970).

\footnotetext{
${ }^{3}$ Ministerstwo Finansów, Najwyższa Izba Kontroli, Regionalna Izba Obrachunkowa, usługodawcy zewnętrzni.
} 
Rozporządzenie Ministra Finansów z dnia 24 czerwca 2006 r. w sprawie kwot, których przekroczenie powoduje obowiązek prowadzenia audytu wewnętrznego w jednostkach sektora finansów publicznych (Dz.U. nr 112, poz. 763).

Tylka, A. (2005). Poradnik audytora wewnętrznego jednostek sektora finansów publicznych. Gdańsk: ODDK.

Ustawa z dnia 26 listopada 1998 r. o finansach publicznych (t.j. Dz.U. nr 155, poz. 1014).

Ustawa z dnia 30 czerwca 2005 r. o finansach publicznych (t.j. Dz.U. nr 249, poz. 2104).

Ustawa z dnia 27 sierpnia 2009 r. o finansach publicznych (t.j. Dz.U. 2016, poz. 1870 z późn. zm.).

\title{
ASSESSMENT OF INTERNAL AUDIT REGULATIONS IN POBLIC FINANCE SECTOR ENTITIES IN THE PERIOD 1998-2016
}

\begin{abstract}
Purpose - The aim of this article is to analyse the functioning of internal audit in Poland in the aspect of the legal regulations.

Design/methodology/approach - Comparative analysis, logical inference.

Findings - Indication of legal solutions influencing the functioning of the public finance sector units and assessment of internal audit.

Originality/value - Analysis of legal regulations defining the functioning of internal audit allowed to indicate solutions influencing on the effectiveness of the organized control and supervision system resulting from Poland's accession negotiations with the EU. The legal interpretation was supported by empirical research. The scientific value of the work is to broaden the knowledge of the impact of regulation on the functioning of internal audit.
\end{abstract}

Keywords: internal audit, regulatory analysis, evaluation of the implementation and coordination of audit, internal audit evaluation criteria

\section{Cytowanie}

Sojka, K. (2017). Analiza funkcjonowania audytu wewnętrznego w Polsce w aspekcie obowiązujących regulacji prawnych. Finanse, Rynki Finansowe, Ubezpieczenia, 3 (87/1), s. 187-195. DOI: 10.18276/frfu.2017.87/1-17. 